\title{
STUDY ON THE LAW OF MINING STRESS EVOLUTION AND FAULT ACTIVATION UNDER THE INFLUENCE OF NORMAL FAULT
}

\author{
Quan-sen WU ${ }^{1)}$, Li-shuai JIANG ${ }^{1)^{*}}$ and Quan-lin WU ${ }^{2)}$ \\ ${ }^{1)}$ State Key Laboratory of Mining Disaster Prevention and Control Co-founded by Shandong Province and the Ministry of Science and \\ Technology, Shandong University of Science and Technology, Qingdao Shandong 266590, China \\ ${ }^{2)}$ Department of Chemistry and Chemical Engineering, Jining University, Qufu Shandong 273100, China \\ *Corresponding author's e-mail: j1sh1989@126.com
}

\section{ARTICLE INFO}

Article history

Received 29 September 2016

Accepted 9 February 2017

Available online 1 September 2017

Keywords:

Normal fault

Mining stress distribution

Fault activation

Energy evolution

Rock burst hazard

\begin{abstract}
Using the $\mathrm{FLAC}^{3 \mathrm{D}}$ numerical simulation method, the characteristics of mining stress evolution, fault activation patterns, and fault energy evolution characteristics are simulated and analyzed in the process of the footwall and hanging wall working face heading to a normal fault. The study shows that the fault cut off the mining stress propagation of overlying strata, and the stress blocking effect due to the fault is evident. When working faces head towards a fault, the abutment pressure and the vertical stress of the surrounding rock increase first and subsequently decrease. The abutment pressure of the coal wall and fault is highest when the distances to the fault are $40 \mathrm{~m}$ and $30 \mathrm{~m}$ for the footwall and hanging wall working faces, respectively. Moreover, the hanging wall mining stress is higher than the footwall mining stress. Fault activation in high-located strata precedes that in low-located strata when working faces head towards the normal fault. Energy is gradually accumulated before unstable fault events take place because of mining, and fault instability quickly releases a lot of energy. The mining stress concentration and fault activation due to faults easily result in rock bursts and mine seismicity.
\end{abstract}

\section{INTRODUCTION}

Coal is one of the main energy sources in the world and plays an irreplaceable role in the development of the world's economy. With the rapid growth of the economy, demand for coal and its production capacity are increasing, and mine geological conditions have become considerably complex. Several coal mines are in complex structural zones. In underground geological structures, faults are the most common geological structure. This has a significant influence on mining design, rational layout, safe production, and mining technology. The existence of faults disrupts the entire continuity of coal and rock strata; hence, the original rock stress in the fault area is changed. Affected by mining, faults are easily activated, which could cause mine dynamic disasters. Therefore, faults are an important restrictive factor in the safety of mine production.

Production practice has proved that rock bursts and microseism easily occur when mining in the vicinity of a fault (Alber et al., 2009; Chen et al., 2012; Cianciara et al., 2008; Aguado et al., 2009; Gaviglio, 1985; Cao et al., 2009). In China, it is found that the stress distribution of the original rock near a fault and the distribution of abutment pressure significantly vary, according to rock burst hazards of several mining areas and rock pressure monitoring systems. According to unfinished statistical reports (Lan et al., 2011), rock bursts caused by faults and other geological tectonic factors accounted for $64.18 \%$. A recorded rock burst accident with a release of $2.2 \times 10^{7} \mathrm{~J}$ energy occurred in the tunneling area of 1410 tailentry in a coal mine that was caused by F9 fault activation. Similarly, due to F16 fault activation, a very serious rock burst accident occurred during the tunneling process in 21221 headentry in a coal mine, which caused more than $400 \mathrm{~m}$ of roadway damage. The microseismic monitoring of a coal mine 3210 working face show that microseismic events mainly concentrate at the front of a working face of the fault zone. Therefore, fault activation has become one of the main factors that induce dynamic disasters in mines. The mining induced dynamic disasters have become an unforeseen danger for the safety of coal mine production.

Fault cutting destroys the integrity of the rock strata, which stops the propagation of mining stress, and the stress field near faults will be singular. Abnormal concentration of mining stress near faults will cause the dynamic disaster of rock burst (Liu et al., 2014; Wang et al., 2010). The frequency and intensity of rock 5 bursts that occur in the face or roadway increase significantly when the working face is heading towards the fault. Some scholars have 
established the model of fault coal pillar and analyzed the law of overlying strata movement and the stability of coal pillar (Li et al., 2010). Using the fault slip mechanics model, the mechanism of rock bursts caused by fault instability is revealed (Liu et al., 2015). Based on the two-dimensional finite element method, the relationship between the excavation position and tangential displacement increment of faults is studied. In the case of fault slip, the change of slip bands in fault slip is studied using the MohrCoulomb failure criterion (Hofmann and Scheepers, 2011). Based on the analysis of the faults that occurred at four coal mines in China, the relationship between the rock burst hazard zone and the fault is obtained (Cao et al., 2001). The stability of rock mass near the fault was evaluated using microseismic monitoring system (Jian et al., 2016). Considering the Silesia coal basin fault in Poland as the research subject, the uneven stress distribution near the fault is obtained (Marcak and Mutke, 2013; Yu et al., 1998) studied the fractal interface effect of fault activation, and they also analyzed the relationship between fault surface fractal properties and rock destruction and surface subsidence. Based on theoretical analysis, numerical simulation and field test, the mechanism of deformation and instability of the tail gate near fault was studied (Shuai et al., 2012). The change law of stress and displacement of fault plane were studied using numerical simulation ( $\mathrm{Li}$ et al., 2008). The characteristics of stress change near fault were studied using numerical simulation (Islam et al., 2009). By monitoring the AE activity of the fault zone, the influence of mining activity on the fault zone was analyzed (Naoi et al., 2015).

Previous researches on the fault mainly focused on the mechanism of instability and the prevention and control of rock bursts. In addition, there are few studies regarding the evolution of mining stress and fault activation under the influence of normal faults. In this study, according to the situation in the front side of the working face, a three-dimensional numerical simulation software, FLAC ${ }^{3 \mathrm{D}}$, which widely employed in ground stability analysis in underground coal mines (Jiang et al., 2016), is used to study the influence of normal faults on the dynamic stress evolution and fault activation law. The main research objectives of this study are: (1) determining the evolution characteristics of mining stress when the hanging wall and footwall working faces head towards a fault; (2) obtaining the shear stress and normal stress evolution characteristics when the hanging wall and footwall working faces head towards a fault and further analyze the law of fault activation; (3) reconstructing the energy accumulation and dissipation processes of the fault during the process of the working face heading. The research results will provide some guidance for the prediction and prevention of rock bursts that occur in working faces, which are affected by the cutting of normal fault, it also has important application value for promoting the safe and efficient mine production.

\section{ENGINEERING BACKGROUND AND NUMERICAL SIMULATION METHOD \\ 2.1. ENGINEERING BACKGROUND}

Xing Long-zhuang coal mine is located in the north wing of Yan Zhou syncline, the depth of 3 coal seam of 7 district is approximately $500 \mathrm{~m}$, and the average thickness of the coal seam is approximately $8 \mathrm{~m}$, and the length of working face is approximately $180 \mathrm{~m}$. The geological structure in the area is complex, and the normal faults for which the fault throw is greater than $5 \mathrm{~m}$. Three main faults are parallel to the coal wall of the working face when the working face advances through, which are DF9, DF10 and DF16, with fault throws of $5 \mathrm{~m}, 8 \mathrm{~m}$ and $9 \mathrm{~m}$ respectively.

\subsection{NUMERICAL CALCULATION MODEL}

Taking the geological condition of 7302 working face of 7 district in Xing Long-zhuang coal mine as the background, the author established the calculation model using the FLAC ${ }^{3 \mathrm{D}}$, studied the evolution law of mining stress, elastic energy distribution characteristics and fault activation pattern when the working face headed towards the normal fault. The model size is $531 \mathrm{~m}$ (length) $\times 260 \mathrm{~m}$ (width) $\times 140 \mathrm{~m}$ (height), and the simulation of the buried depth of the coal seam is $500 \mathrm{~m}$; the fault dip angle is $60^{\circ}$; the fault throw is $8 \mathrm{~m}$; the coal seam thickness is $8 \mathrm{~m}$, as shown in Figure 1. The load on the top of the model is simulated by applying $9 \mathrm{MPa}$ uniformly distributed load on the top of the model. The top of the model is applied to the uniform load of $9 \mathrm{MPa}$, and the load on the top of the model is simulated. In the horizontal direction, the trapezoidal distribution load is 0.5 times that of the vertical direction; $Y$ direction displacement is restricted before and after the $\mathrm{Y}$ boundary, and the $\mathrm{Z}$ direction displacement is restricted at the bottom surface, and the other surface displacement is set free. The fault zone is simulated with $1 \mathrm{~m}$ wide weak and soft zone (Naoi et al., 2015). In the process of simulation, the Mohr-Coulomb failure strength criterion is adopted (Jiang et al., 2014). The physical parameters of the rock mass are listed in Table 1.

As shown in Figure 2, monitoring points are set at a distance of $8 \mathrm{~m}$ and $50 \mathrm{~m}$ from the coal seam in the fault zone at the midpoint, respectively, as the fault activation markers, which record the characteristics of dynamic changes in the parameters in the process of mining. Here, $A$ and $B$ are the measuring points of the footwall of fault, and $\mathrm{A}^{\prime}$ and $\mathrm{B}^{\prime}$ are the measuring points of the hanging wall of fault.

\section{EVOLUTION LAW OF MINING STRESS IN WORKING FACE \\ 3.1. WORKING FACE STRESS EVOLUTION LAW DURING FOOTWALL MINING}

When the footwall working face is heading towards the fault, the vertical stress distribution of the 
Table 1 Parameters of mechanics and strata of model.

\begin{tabular}{lccccccc}
\hline Rock strata & $\begin{array}{c}\text { Thickne } \\
\mathrm{ss}(\mathrm{m})\end{array}$ & $\begin{array}{c}\text { Density } \\
\left(\mathrm{kgm}^{-3}\right)\end{array}$ & $\begin{array}{c}\text { Bulk modulus } \\
(\mathrm{GPa})\end{array}$ & $\begin{array}{c}\text { Shear modulus } \\
(\mathrm{GPa} 0\end{array}$ & $\begin{array}{c}\text { Cohesion } \\
(\mathrm{MPa})\end{array}$ & $\begin{array}{c}\text { Tensile } \\
\text { strength }(\mathrm{MPa})\end{array}$ & $\begin{array}{c}\text { Friction angle } \\
(\mathrm{deg}) /^{\circ}\end{array}$ \\
\hline Sandstone & 20 & 2520 & 18.3 & 11.5 & 1.2 & 3.96 & 41 \\
Claystone & 28 & 2300 & 15.2 & 6.25 & 0.1 & 1.55 & 31 \\
Sandstone & 8 & 2520 & 18.3 & 11.5 & 1.2 & 3.96 & 41 \\
Claystone & 4 & 2300 & 15.2 & 6.25 & 0.1 & 2.8 & 31 \\
Siltstone & 8 & 2530 & 13.4 & 7.6 & 1.4 & 1.85 & 37 \\
Sandstone & 28 & 2520 & 18.3 & 11.5 & 1.2 & 3.96 & 41 \\
Siltstone & 8 & 2530 & 13.4 & 7.6 & 1.4 & 1.85 & 37 \\
3Coal & 8 & 1350 & 10.5 & 6.5 & 1.2 & 0.5 & 23 \\
Fine sandstone & 4 & 2530 & 13.4 & 7.6 & 1.4 & 4.0 & 37 \\
Sandstone & 12 & 2520 & 18.3 & 11.5 & 1.2 & 3.96 & 41 \\
Mudstone & 12 & 2340 & 9.8 & 7.1 & 0.5 & 3.0 & 39 \\
Fault & 1 & 2000 & 0.01 & 0.0035 & 0.001 & 0.2 & 5 \\
\hline
\end{tabular}

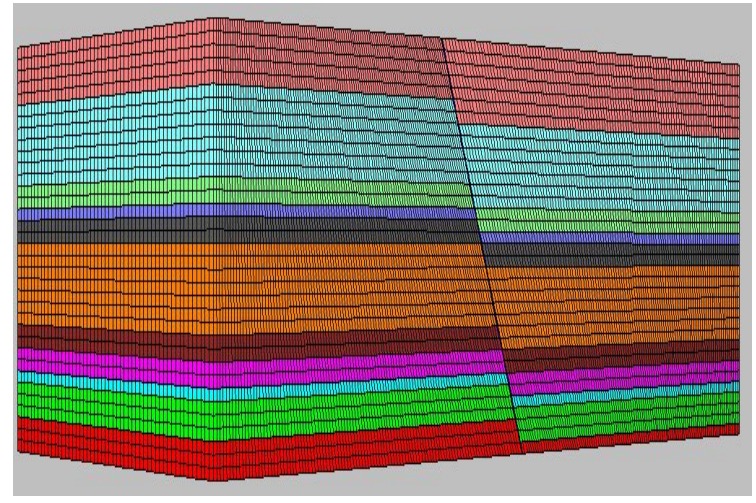

Fig. 1 Computational model mesh generation.

central working face with different distances from the fault is shown in Figure 3.

Figure 3 shows that the fault zone stress is much lower than the original rock stress, which is due to several factors such as the ease with which the fault zone coal rock mass is broken, low strength, low cohesion, low tensile strength and the difficulty of forming stress concentration.

According to Figure 3(a), when the working face is $80 \mathrm{~m}$ apart from the fault, the overlying strata between the fault and working face are wedge-shaped, which is due to the cutting action of the fault. As the roof is prone to large area movement, the stress concentration of the roof and floor is high; the vertical stress is in the range of $24-26 \mathrm{MPa}$; the stress concentration coefficient is in the range of 1.92-2.08, and the stress concentration of the roof is greater than that of the floor. On the outer side of the fault, the overlying strata are inverted wedge, and the stress concentration of the top floor is not high, which is slightly higher than that of the original rock. The fault zone is affected by tectonic stress, and the vertical stress is higher than that of the original rock.

As shown in Figures 3(b) and 3(c), when the distances of the working face from the fault are $50 \mathrm{~m}$

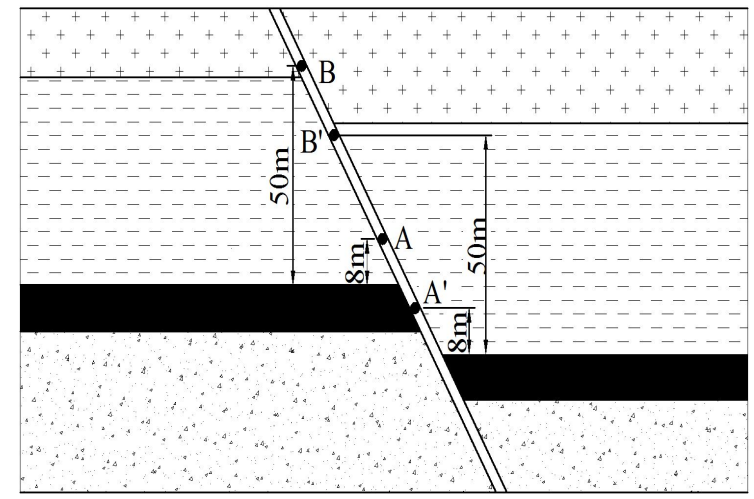

Fig. 2 Schematic of the arrangement of fault activation monitoring points.

and $40 \mathrm{~m}$, the barrier function of the fault zone is more evident, which blocks the propagation of the mining stress, resulting in the stress between the working face and the fault and the roof stress to increase. When the distance of the working face from the fault is $40 \mathrm{~m}$, the stress concentration in front of the working face is the highest, and the vertical stress level is in the range of $25-31 \mathrm{MPa}$, and the stress concentration factor is 2-2.48. The vertical stress gradually increases near the fault zone.

From Figures 3(c) and 3(d), the working surface and the fault distance reduces from $40 \mathrm{~m}$ to $10 \mathrm{~m}$, and the roof and floor and coal seam stress concentrations decrease. When the distance of the working face from the fault is $10 \mathrm{~m}$, the top and bottom of the vertical stress level is low, lower than that of the original rock stress. The roof is in unloading pressure, stress is released.

From Figure 3 we can see that when the working face is advancing, the fault blocking effect is quite clear, and the vertical stress concentration between the coal wall and the fault gradually increase.

Figure 4 shows the abutment pressure distribution of the coal seam and direct roof interface in the middle of the working face when the footwall 


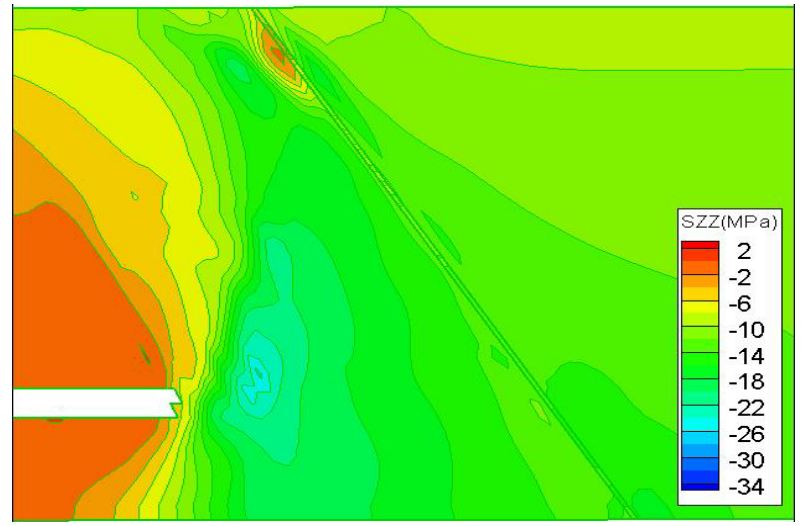

(a) Distance from working face to fault: $80 \mathrm{~m}$

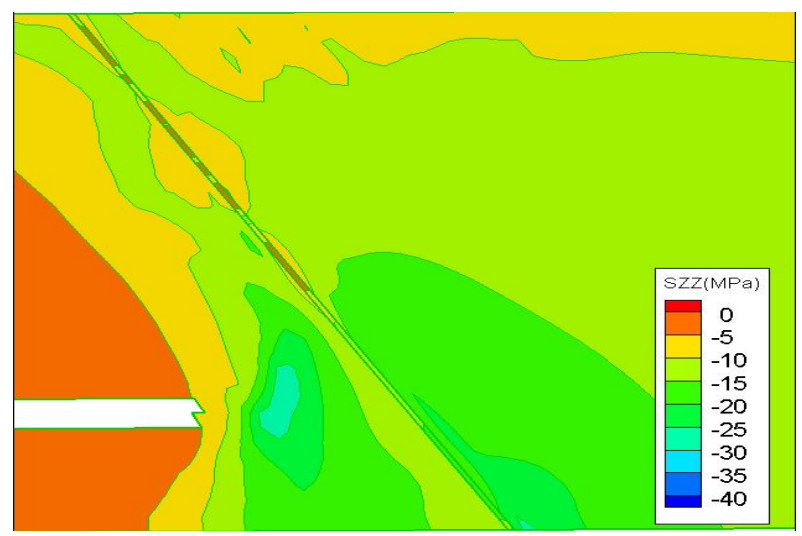

(c) Distance from working face to fault: $40 \mathrm{~m}$

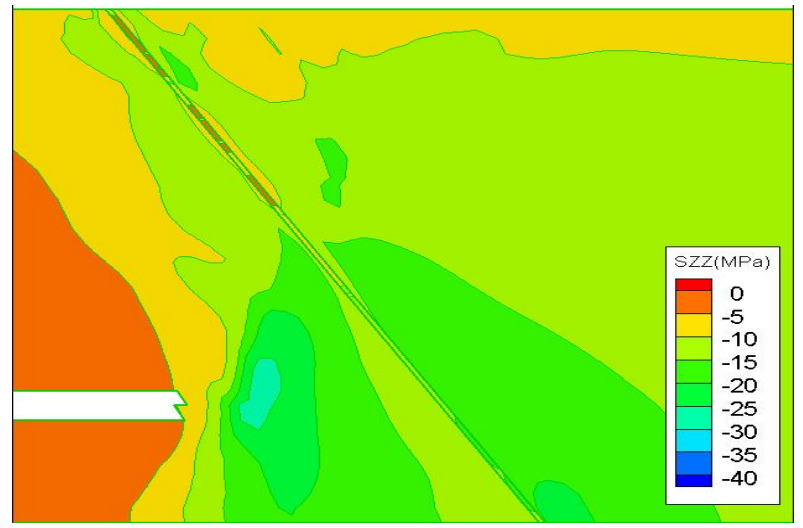

(b) Distance from working face to fault: $50 \mathrm{~m}$

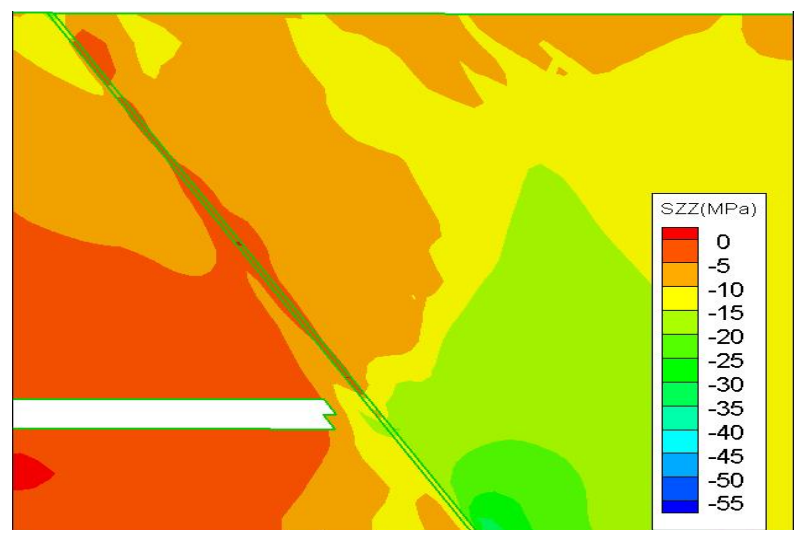

(d) Distance from working face to fault: $10 \mathrm{~m}$

Fig. 3 Vertical stress distribution with different distances away from the fault when mining in footwall.

working face advances towards the fault. We can see from Figure 4 that when the distance between the working face and the fault reduces from $90 \mathrm{~m}$ to $40 \mathrm{~m}$, due to the cutting action of fault, stress concentration degree in front of the coal wall is high, and the front abutment pressure peak increased gradually from 25.05 $\mathrm{MPa}$ to $30.7 \mathrm{MPa}$. The change in the abutment pressure in front of the fault is small, and the concentration degree is low, which is slightly higher than that of the original rock stress.

When the distance between the working face and fault decreases from $40 \mathrm{~m}$ to $10 \mathrm{~m}$, the bearing capacity of the coal pillar decreases, and the front abutment pressure gradually decreases, and the stress transfers to the high-located strata, which have a strong bearing capacity. When the working face is

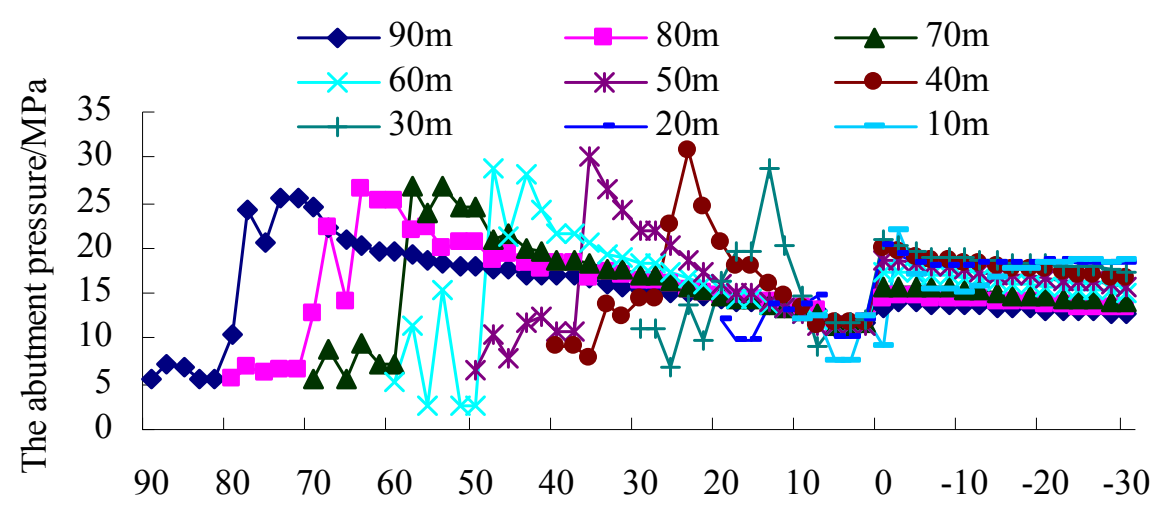

The distance from working face to fault $/ \mathrm{m}$

Fig. 4 Abutment pressure distribution of footwall working face. 


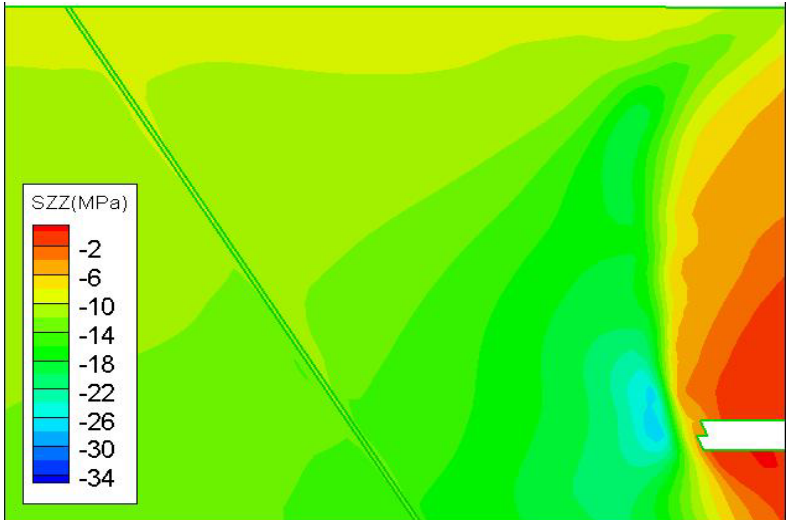

(a) Distance from working face to fault: $80 \mathrm{~m}$

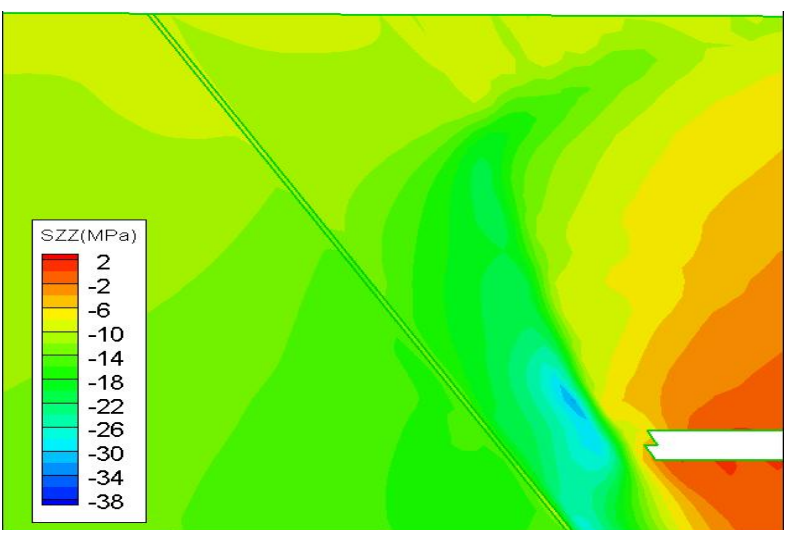

(c) Distance from working face to fault: $30 \mathrm{~m}$

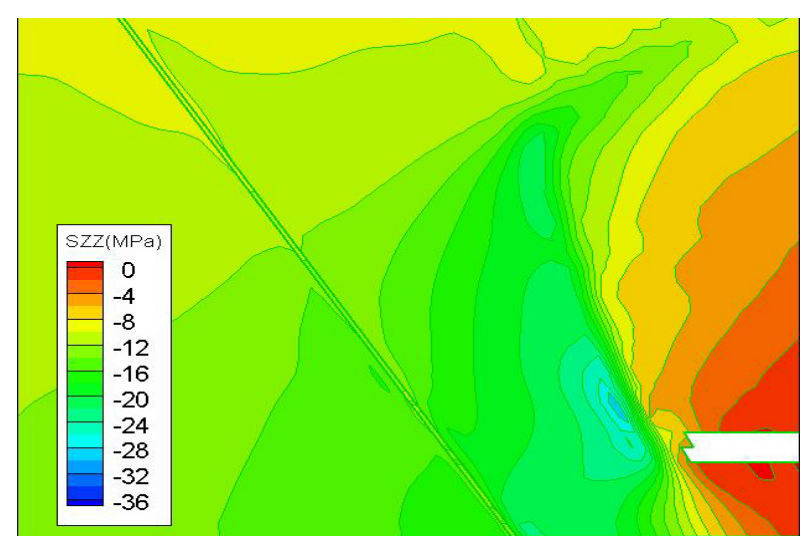

(b) Distance from working face to fault: $50 \mathrm{~m}$

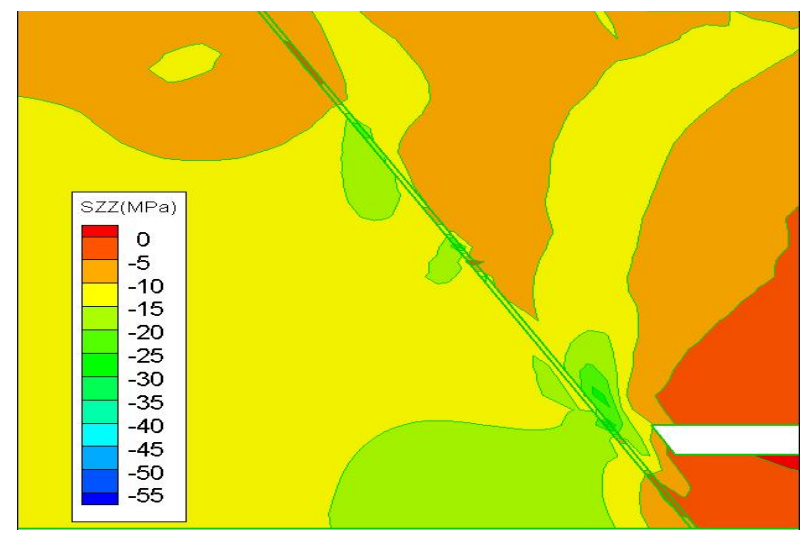

(d) Distance from working face to fault: $10 \mathrm{~m}$

Fig. 5 Vertical stress distribution with different distances away from the fault when mining in hanging wall.

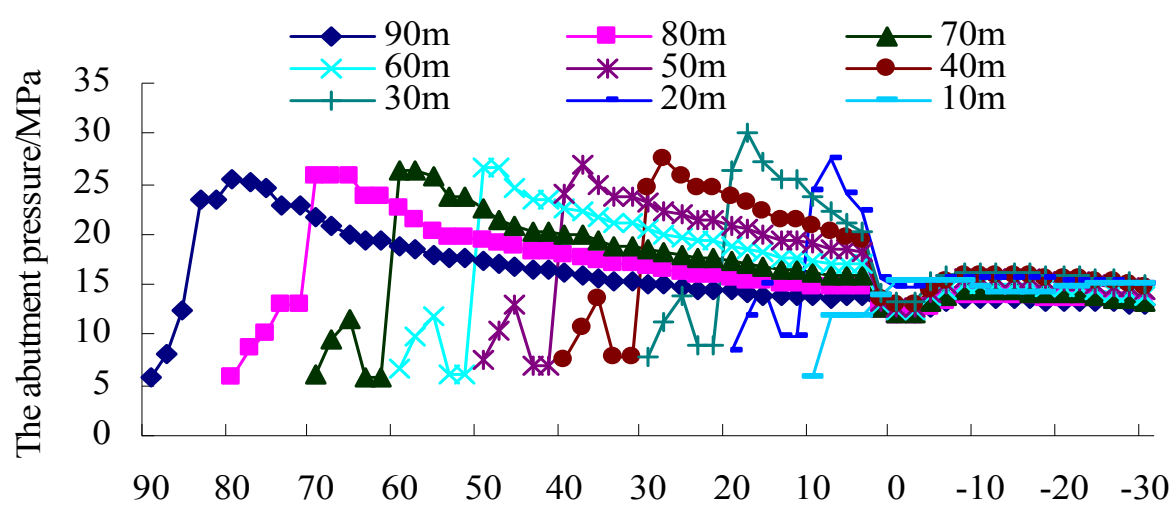

The distance from working face to fault $/ \mathrm{m}$

Fig. 6 Abutment pressure distribution of hanging wall working face.

$10 \mathrm{~m}$ apart from the fault, the stress on the coal body is much higher than that of the coal bearing limit; the coal body is destroyed, and the peak of the front abutment pressure of the coal wall is only $12.4 \mathrm{MPa}$, which is close to the original rock stress.

\subsection{WORKING FACE STRESS EVOLUTION LAW DURING HANGING WALL MINING}

Figure 5 shows the vertical stress in the middle of the working face with different distances from fault when the footwall working face is advancing towards the fault.

As shown in Figure 5, the stress concentration of the fault zone is low, and the vertical stress level is close to the original rock stress. Figure 5(a) shows that when the working face is $80 \mathrm{~m}$ away from the fault, the faults will cut the overburden into an inverted wedge, because of the cutting action of fault, a large area movement also occur in the roof, roof and floor are in high stress state; the vertical stress is in the 
range of 21-24 Mpa; the stress concentration coefficient is in the range of 1.68-1.92, and the stress concentration degree of the bottom is lower than that of the roof. Figures 5(b) and 5(c) show that the cutting effect of the fault is evident, and the stress blocking effect is more prominent in the fault zone, in the deceasing order of distance between the working face and the fault; the roof and floor has been in a high stress state, and the degree of stress concentration gradually increases. When the working face is $30 \mathrm{~m}$, the vertical stress level is in the range of 26-32 $\mathrm{MPa}$, and the stress concentration factor is in the range of 2.08-2.56. From Figure 5d, when the distance between the working face and the fault reduces to $10 \mathrm{~m}$, the roof and floor are in the pressure-relief state, and the vertical stress level is close to the original rock stress.

Figure 6 shows the abutment pressure distribution of the coal seam and the direct roof interface in the middle of the working face when the hanging wall working face advances towards the fault. Figure 6 shows that when the distance between the working face and the fault is reduced from $90 \mathrm{~m}$ to $30 \mathrm{~m}$, the front abutment pressure peak gradually increased from 26.7 $\mathrm{MPa}$ to $31.1 \mathrm{MPa}$. With the distance between the working face and the fault continues to decrease, the front abutment pressure transfers, and the peak gradually decreases. When the working face is $10 \mathrm{~m}$ apart from the fault, the peak value of the front abutment pressure reduces to 13.9 $\mathrm{MPa}$. Compared to the footwall working face, the roof and floor stress concentration degree of the hanging wall working face is higher.

When the work is heading towards the fault, the barrier effect of the fault zone is evident, and the stress distribution of the overlying strata is cut off; the stress distribution on the two sides of the fault is different, and the stress concentration of the roof and floor of the fault coal pillar is relatively high. When the footwall working face is advancing to the fault, inside the fault, the overlying strata are wedge-shaped; the abutment pressure and the vertical stress of surrounding rock increases first and subsequently decrease. When the working face is $40 \mathrm{~m}$ away from the fault, in the middle of the working face, the maximum value of the support pressure is reached. Outside the fault, the vertical stress concentration of the surrounding rock is not high. The mining stress evolution law when the hanging wall advances to the fault is the same as that of the footwall. When the working face is $30 \mathrm{~m}$ away from the fault, the abutment pressure in the middle of the working face reaches the maximum value, and the abutment pressure and the vertical stress concentration is higher than that of the footwall. When the footwall or hanging wall working faces advances towards the fault, the vertical stress concentration degree of surrounding rock is high, hereby the rock burst potential increases.

\section{DISTRIBUTION CHARACTERISTICS OF ELASTIC ENERGY OF WORKING FACE \\ 4.1. DISTRIBUTION CHARACTERISTICS OF ELASTIC ENERGY DURING FOOTWALL MINING}

Figure 7 shows the distribution of the coal and rock elastic properties with different distance to fault when the footwall working face is advancing towards the fault.

From Figure 7, it is evident that due to the cutting effect of the entry, the energy concentration degree of the two ends of the working face coal body is much higher than that in the middle of the working face area. From Figure 7(a), when the distance between the working face and fault is $80 \mathrm{~m}$, the energy density in the central area of the working face is in the range of $15-18 \mathrm{~kJ} / \mathrm{m}^{3}$, and the energy density of the two ends is in the range of $29-31 \mathrm{~kJ} / \mathrm{m}^{3}$, which is the highest. When the distance between the working surface and fault reduces to $50 \mathrm{~m}$, the degree of energy concentration is further increased, and the central area of the working face energy density reaches a range of $17-19 \mathrm{~kJ} / \mathrm{m}^{3}$. The energy density at both ends increases to a range of $31-33 \mathrm{~kJ} / \mathrm{m}^{3}$ (Fig. 7(b)). As the distance between the working face and the fault continues to reduce, the blocking effect of the fault is evident, which blocks the energy to pass through the front of the fault. Figure 7(c) shows that when the working face is $40 \mathrm{~m}$ away from the fault, the energy concentration degree is the highest. In the middle of the working face, the energy density reaches a range of $21-23 \mathrm{~kJ} / \mathrm{m}^{3}$, and the energy density at both ends is in the range of $34-36 \mathrm{~kJ} / \mathrm{m}^{3}$. When the distance between the working face and the fault reduces from $40 \mathrm{~m}$ to $10 \mathrm{~m}$, the energy concentration in front of the coal wall gradually reduces, and the energy transfers to both the sides of the working face coal body.

Figure 8 shows the distribution of the elastic energy in the central part of the working face when the footwall working face is heading towards the fault. From Figure 8, we can see that the elastic energy distribution is the same as that of the abutment pressure distribution when the working face is heading towards the fault. When the distance between the working face and fault reduces from $90 \mathrm{~m}$ to $40 \mathrm{~m}$, the energy concentration in front of the working face is increasing, and the energy density increases from $18.3 \mathrm{~kJ} / \mathrm{m}^{3}$ to $25.6 \mathrm{~kJ} / \mathrm{m}^{3}$. When the distance between the working face and fault continues to reduce, the energy concentration is gradually decreases. When the working face is $10 \mathrm{~m}$ away from the fault, the energy density reduces to $5.5 \mathrm{~kJ} / \mathrm{m}^{3}$.

\subsection{DISTRIBUTION CHARACTERISTICS OF ELASTIC ENERGY DURING HANGING WALL MINING}

Compared to the footwall mining, the energy concentration degree in front of the working face when mining in hanging wall is greater than that of 


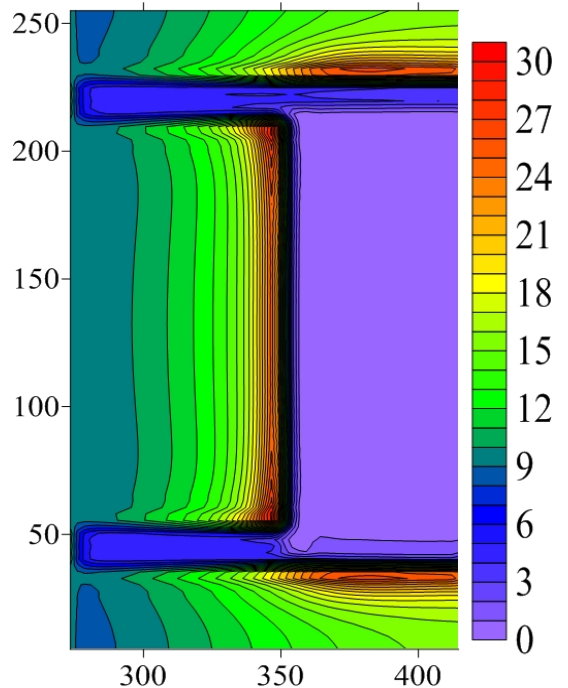

(a) Distance from working face to fault: $80 \mathrm{~m}$

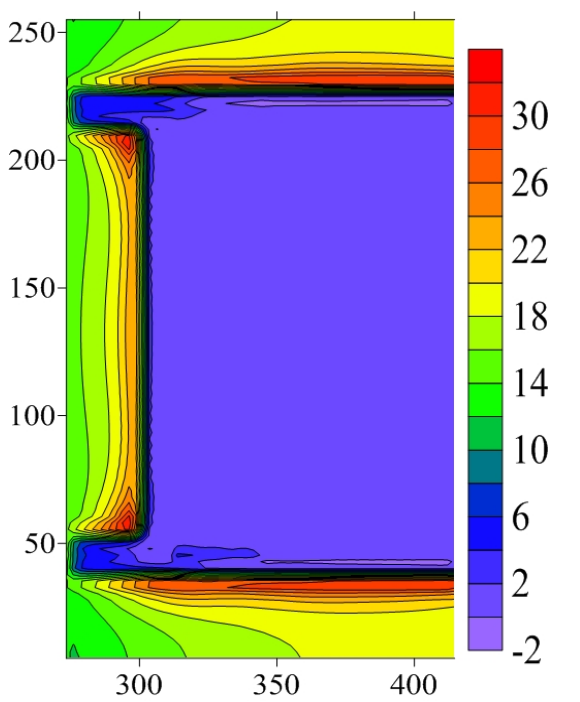

(c) Distance from working face to fault: $30 \mathrm{~m}$

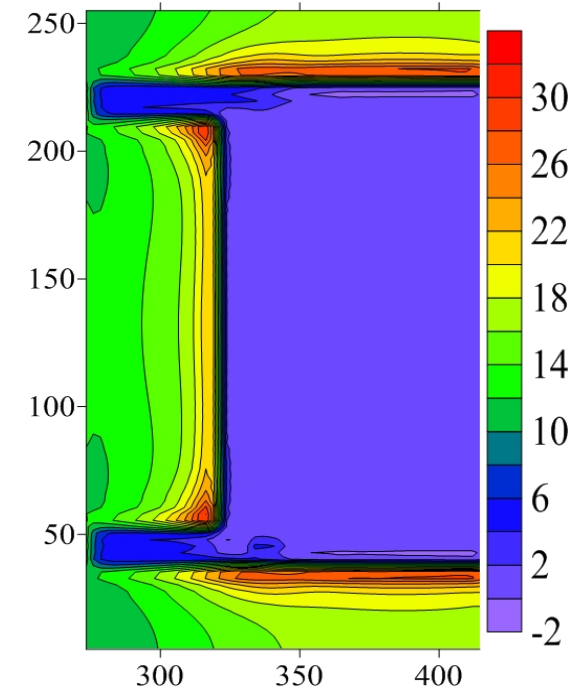

(b) Distance from working face to fault: $50 \mathrm{~m}$

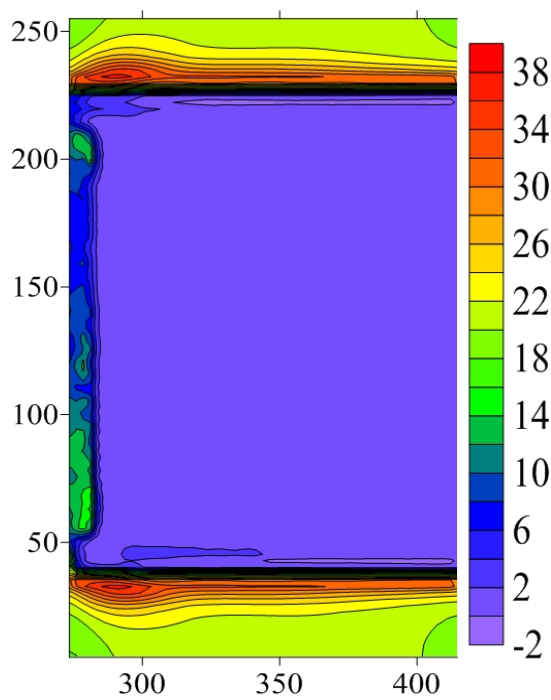

(d) Distance from working face to fault: $10 \mathrm{~m}$

Fig. 7 Distribution of working face elastic energy with different distances away from the fault when mining in footwall.

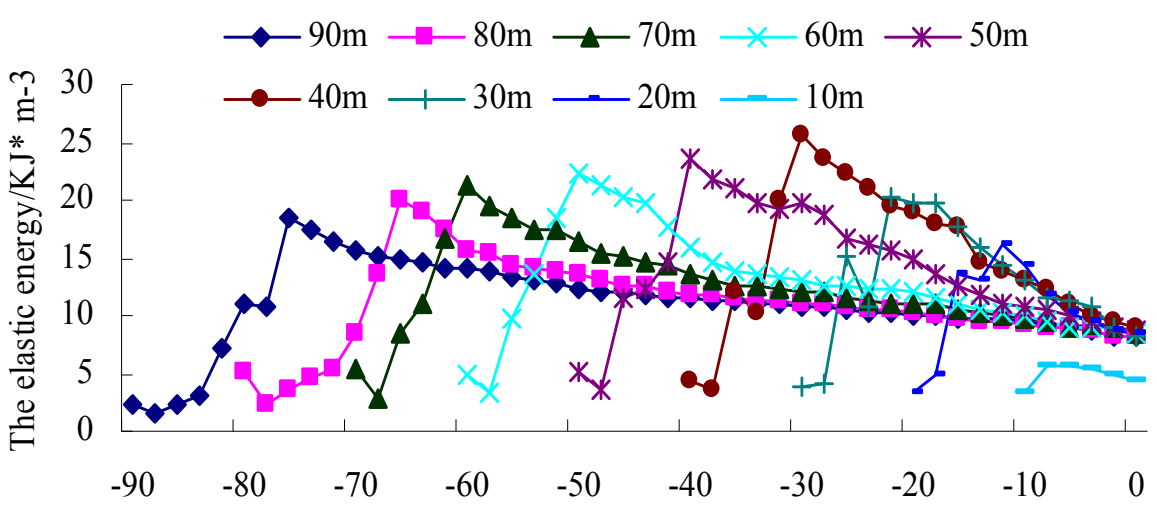

The distance from working face to fault $/ \mathrm{m}$

Fig. 8 Elastic energy distribution of footwall working face. 


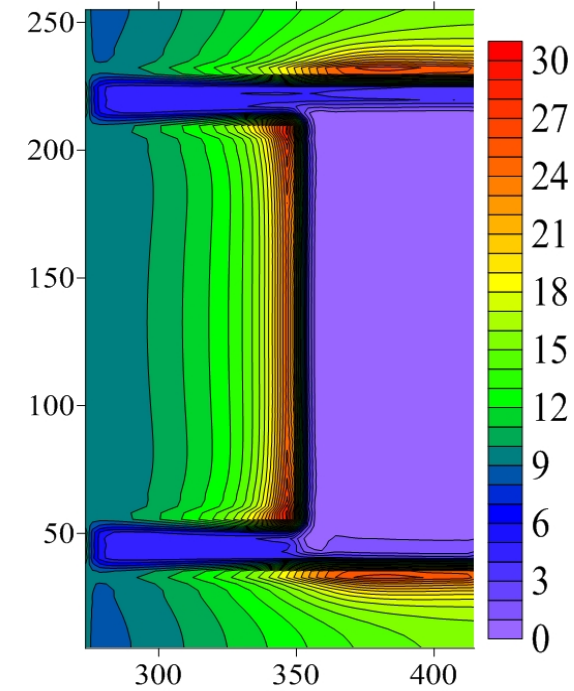

(a) Distance from working face to fault: $80 \mathrm{~m}$

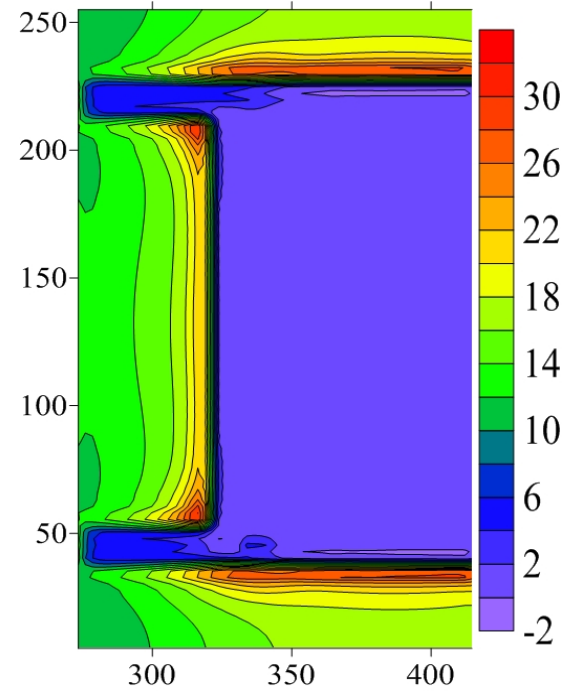

(b) Distance from working face to fault: $50 \mathrm{~m}$

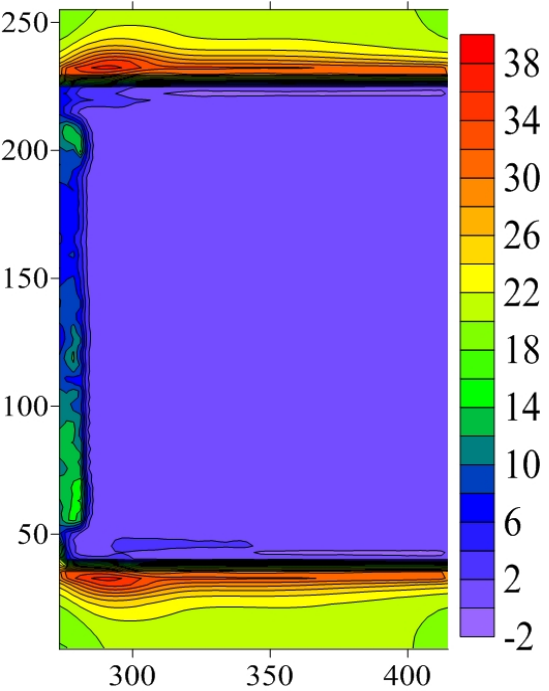

(d) Distance from working face to fault: $10 \mathrm{~m}$

(c) Distance from working face to fault: $30 \mathrm{~m}$

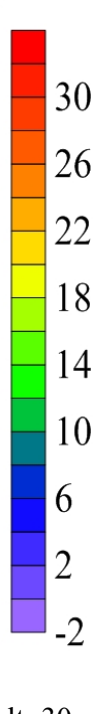

Fig. 9 Distribution of working face elastic energy with different distances away from the fault when mining in hanging wall.

mining in footwall, and the energy distribution is relatively uniform in the direction of inclination (Fig. 9). When the distance between the working face and fault decreases from $80 \mathrm{~m}$ to $30 \mathrm{~m}$, the energy concentration degree in front of the working face increases gradually. In addition, in the middle of the working face area, the energy density value increases from $20-23 \mathrm{~kJ} / \mathrm{m}^{3}$ to $30-32 \mathrm{~kJ} / \mathrm{m}^{3}$, and the energy density of the two ends increases from $22-24 \mathrm{~kJ} / \mathrm{m}^{3}$ to 33-35 kJ/m $3 \mathrm{~m}^{3}$ (Figs. 9(a)-9(c)). Figure 9 (d) shows that when the distance between the working face and fault is reduced to $10 \mathrm{~m}$, coal energy has been released in the influence of mining; the accumulation of energy in front of the working face is low; the value of energy density is only in the range of $3-5 \mathrm{~kJ} / \mathrm{m}^{3}$.

Figure 10 shows the coal seam elastic energy distribution in the middle of the working face when the hanging wall working face is heading towards the fault. As shown in Figure 10, when the distance between the working face and fault reduces from $90 \mathrm{~m}$ to $30 \mathrm{~m}$, the maximum elastic energy in front of the working face increases continuously from $22.54 \mathrm{~kJ} / \mathrm{m}^{3}$ to $31.42 \mathrm{~kJ} / \mathrm{m}^{3}$. With the reduction of the distance between the working face and fault, the width of the bearing coal pillar decreases gradually, and the energy that accumulates in the coal body is transferred and released. The energy density in front of the working face constantly reduces. When the working face is $10 \mathrm{~m}$ away from fault, the energy density is only $5.5 \mathrm{~kJ} / \mathrm{m}^{3}$.

The energy concentration degree in the front of the working face is also higher than that in the footwall working face.

Before the fault instability, the fault energy accumulation increases gradually, during the fault activation, large amounts of energy will be rapidly 


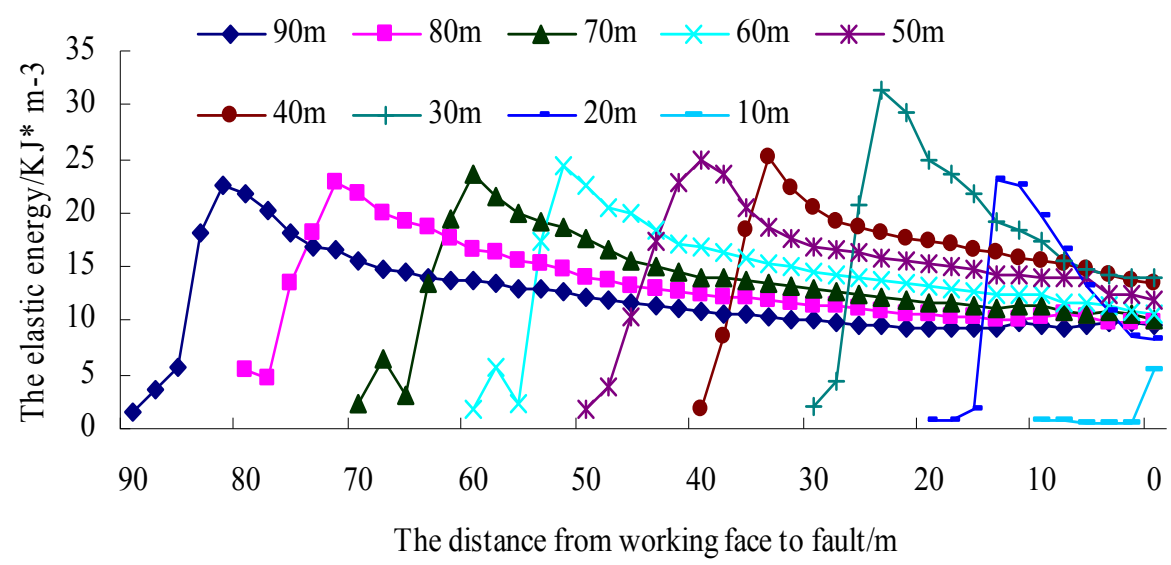

Fig. 10 Elastic energy distribution of hanging wall working face.

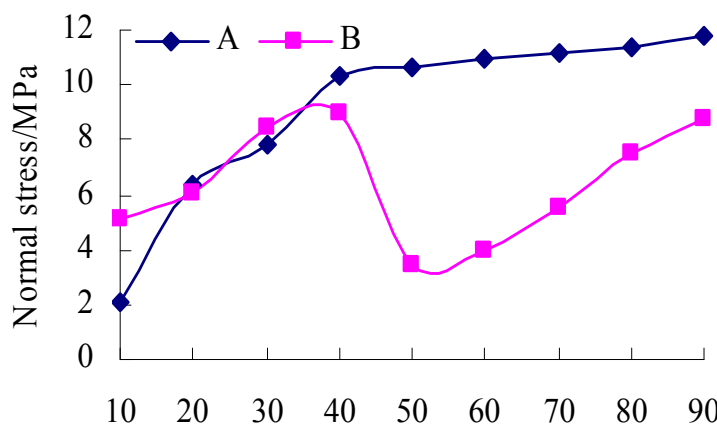

The distance from working face to fault $/ \mathrm{m}$

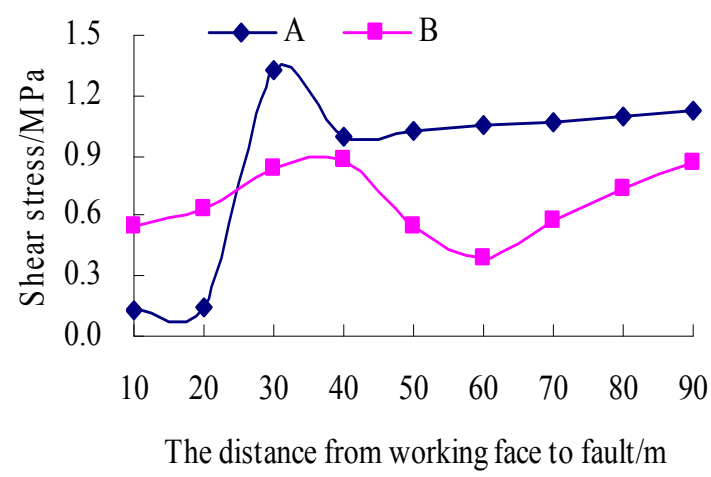

(a)

Fig. 11 Stress change of fault zone mining in footwall.

released, which can easily induce rock bursts, mine seismicity and other dynamic disasters. In addition, the fault energy can be used as an index to estimate the fault stability.

\section{FAULT ACTIVATION LAW IN THE TWO WALLS OF NORMAL FAULT}

\subsection{FAULT STRESS EVOLUTION LAW DURING FOOTWALL MINING}

From the Figure 11(a), the characteristics of stress change on the fault zone have clear spatial effect, and the stress change characteristics of the fault low (measuring point $\mathrm{A}$ in fault zone that is $8 \mathrm{~m}$ away from the coal seam) and the high position (measuring point $\mathrm{B}$ in fault zone that is $50 \mathrm{~m}$ away from the coal seam) are quite different. The normal stress of measuring point $\mathrm{A}$ with the advancing of the working face decreases, but decreases in a small range of 90$40 \mathrm{~m}$ from the working face to the fault. The normal stress reduces from $11.78 \mathrm{MPa}$ to $10.29 \mathrm{MPa}$, and the mining influence is not evident. When the distance between the working surface and fault is in the range of $40-10 \mathrm{~m}$, the normal stress of the measuring point A decreases rapidly, and the normal stress decreases to $2.12 \mathrm{MPa}$ when the distance from the fault is $10 \mathrm{~m}$.
The normal stress of the measuring point $\mathrm{B}$ reduces to the "decrease-increase-decrease" wave type change law, which is not a simple increase or decrease, and the normal stress level is lower. When the working face is $90-50 \mathrm{~m}$ apart from the fault, the normal stress of the measuring point $\mathrm{B}$ reduces from $8.79 \mathrm{MPa}$ to a minimum value $3.43 \mathrm{MPa}$. The normal stress reaches the maximum value of $9.02 \mathrm{MPa}$ with $40 \mathrm{~m}$ distance from fault, and then the normal stress gradually reduces with the advancement of the working face.

In Figure 11(b), the variation law of the shear stress on the fault zone is similar to that of the normal stress. A point shear stress is less affected by mining activity in the 90-40 $\mathrm{m}$ range of working face distance to fault. When the working face is $30 \mathrm{~m}$ apart from the fault, the shear stress reaches a maximum value of $1.32 \mathrm{MPa}$, and the shear stress decreases rapidly to $0.13 \mathrm{MPa}$ at $20 \mathrm{~m}$ from the working face. When the working face is $60 \mathrm{~m}$ from the fault, the shear stress of the measuring point $\mathrm{B}$ is released quickly and reduced to $0.386 \mathrm{MPa}$. When the working face is $40 \mathrm{~m}$ from the fault, the shear stress suddenly increases to a maximum value of $0.88 \mathrm{MPa}$. With the distance between the working face and fault continues to 


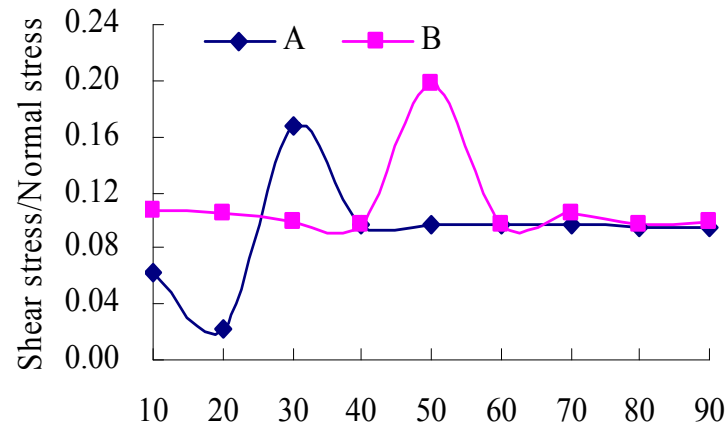

The distance from working face to fault $/ \mathrm{m}$

Fig. 12 The ratio of shear stress to normal stress mining in the footwall.

decrease, the $\mathrm{B}$ point shear stress decreases continuously.

\subsection{FAULT ACTIVATION HAZARD ANALYSIS DURING FOOTWALL MINING}

In order to study the possibility of the activation of the two walls of the fault, the ratio of shear stress to normal stress in the fault zone was selected as the research index (Jiang et al., 2013). Figure 12 shows that the shear stress and normal stress ratio change law of the measuring points $\mathrm{A}$ and $\mathrm{B}$ are different; the ratio of measuring point B is a "single peak" distribution state, and the measuring point $\mathrm{A}$ ratio change law is "wave" distribution state. In an area with a distance of 90-40 $\mathrm{m}$ from the working face to fault, the shear stress and normal stress of measuring point $\mathrm{A}$ is in a decreasing trend with the advancing of the working face, and the ratio is increasing, which indicates that the decrease of the shear stress of the measuring point $\mathrm{A}$ is less than the normal stress. In the range of $40-30 \mathrm{~m}$, the measuring point $\mathrm{A}$ ratio increases from 0.1 to 0.17 . According to Figure 11, it can be seen that when the working face is $30 \mathrm{~m}$ away from fault, the shear stress increases to the maximum and the normal stress decreases. In addition, the shear stress and the normal stress ratio of the peak value is 0.17 , indicating that the sensitivity of the shear stress to fault activation is stronger than the normal stress. At this time, the fault is very easily activated and shows instability. Within the range of $30-20 \mathrm{~m}$, the ratio of measuring point $\mathrm{A}$ is in a decreasing trend, which indicates that the fault has activated and is unstable. The change in the ratio of the shear stress to the normal stress is smaller, and the fault zone is relatively stable when the distance between the working surface and fault is more than $50 \mathrm{~m}$. When the working face is pushed $50 \mathrm{~m}$ towards the fault, the ratio increases rapidly to a maximum value of 0.2 , and the fault is easily activated at this time. When the distance from the fault is less than $50 \mathrm{~m}$, the stress ratio reduces, and the fault has activated and is unstable. Clearly, it is earlier that the fault activated and unstable occurs in B point than in A point.

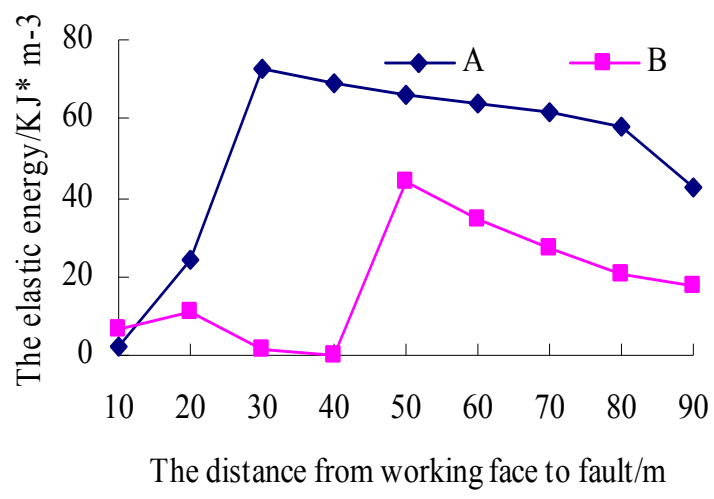

Fig. 13 Footwall mining fault zone energy change.

Therefore, for the footwall mining, high-located rock strata fault activation precedes the immediate roof. The shear stress and normal stress distribution of the fault are similar, indicating that when mining in the footwall, the shear stress effect on the fault activation is higher than that of the normal stress. In the footwall mining, when the working face respectively from the fault are $50 \mathrm{~m}$ and $30 \mathrm{~m}$, the fault in high-located strata and immediate roof are the most likely to be activated and lose stability.

\subsection{FAULT ENERGY EVOLUTION CHARACTERISTICS DURING FOOTWALL MINING}

After mining, free space appears in the underground rock mass, which cause the formation of overlying strata caving zone, fractured zone, bending zone (herein referred to as the "three zones"). When there is a fault geological structure, one of the walls is affected by the mining activity. When the working face is far from the fault, the mining action has little influence on the fault. As the working surface continues to advance, the three zones are developed, and the stress field changes when it reaches the fault, and the fault energy will be changed. From Figure 13, we can see that when the work advances towards the fault, the energy change characteristics of the fault zone are obviously distributed in space, the energy accumulation of the measuring point $\mathrm{A}$ is far greater than the measuring point $B$. Before the fault activation, when the working face reduces from $90 \mathrm{~m}$ to $30 \mathrm{~m}$, the accumulation of the fault energy is increasing, and the energy density increases from $42.87 \mathrm{~kJ} / \mathrm{m}^{3}$ to $72.52 \mathrm{~kJ} / \mathrm{m}^{3}$. When the working face is $20 \mathrm{~m}$ away from fault, due to mining, fault is activated, and the fault zone releases large amounts of energy; the energy density decreases rapidly to $24.52 \mathrm{~kJ} / \mathrm{m}^{3}$, reducing by $70.3 \%$. For measuring point $\mathrm{B}$, before the fault activation, the fault energy change trend is "wave" type distribution, in the range of 90$50 \mathrm{~m}$ from the working surface to the fault. The energy increases rapidly, and the energy density value increased from $17.27 \mathrm{~kJ} / \mathrm{m}^{3}$ to $40.8 \mathrm{~kJ} / \mathrm{m}^{3}$; When the 


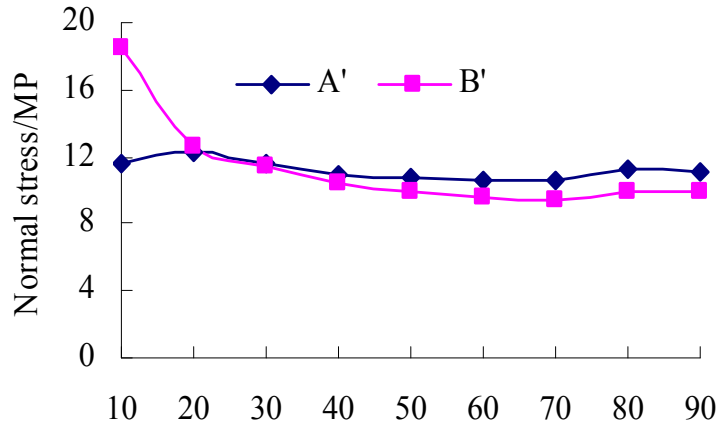

The distance from working face to fault $/ \mathrm{m}$

(a)

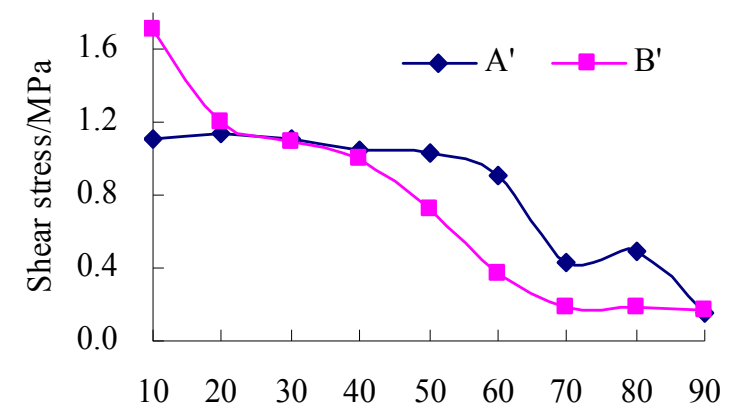

The distance from working face to fault $/ \mathrm{m}$

(b)

Fig. 14 Stress change of fault zone mining in hanging wall.

working face is $40 \mathrm{~m}$ away from fault, fault is activated, which results in rapid release of energy accumulation in the fault zone. The energy density decreases to $0.25 \mathrm{~kJ} / \mathrm{m}^{3}$, reducing by $99.4 \%$. As the working face continues to move forward, energy appears to be in the "increase-decrease-increase" trend. When the working face is $10 \mathrm{~m}$ away from the fault, the energy density value of the fault zone increases to $17.27 \mathrm{~kJ} / \mathrm{m}^{3}$.

Therefore, before the fault activation occurs, the accumulation of energy is gradually increasing, and because of the instability of the fault, there is a rapid release of a large amount of energy, which can easily induce rock bursts, mine seismicity and other dynamic disasters.

\subsection{FAULT STRESS EVOLUTION LAW DURING HANGING WALL MINING}

We can see from Figure 14 that the stress variation in the hanging wall mining fault zone and the footwall mining is different. The evolution characteristics of the fault zone normal stress are basically the same in space (Fig. 21(a)). The normal stress of $\mathrm{A}^{\prime}$ point, which is $8 \mathrm{~m}$ away from the coal seam, is increasing, but the growth rate is small, and the mining activity has little influence on the normal stress level. The stress level is $11 \mathrm{MPa}$ when the working face is $90 \mathrm{~m}$ away from the fault, and the stress level reaches a maximum value of $12.28 \mathrm{MPa}$, and then the stress level decreases slightly with the continuous advancement of the working face, and the distance from the fault is $20 \mathrm{~m}$. The normal stress of $B^{\prime}$ point $(50 \mathrm{~m}$ distance to the coal seam fault zone measuring point) during the advancement of the working face increases from 9.92 $\mathrm{MPa}(90 \mathrm{~m})$ to $10 \mathrm{~m}$ $18.46 \mathrm{MPa}(10 \mathrm{~m})$.

For the $\mathrm{A}^{\prime}$ point, during the advancement of the working face, the change law of the fault shear stress in general shows an increasing trend (Fig. 14 (b)). When the working face is $90-70 \mathrm{~m}$ away from the fault, the shear stress level increases slightly from $0.15 \mathrm{MPa}$ to $0.43 \mathrm{MPa}$. When the working face is $60 \mathrm{~m}$ apart from the fault, the shear stress increases to
$0.91 \mathrm{MPa}$. With the decrease in the distance between the working face and fault, the shear stress increases gradually. When the working face is $20 \mathrm{~m}$ away from the fault, the shear stress reaches a maximum value of 1.14 MPa. When the distance from the working face to the fault is less than $20 \mathrm{~m}$, the stress starts to release and the shear stress decreases. For the B' point, during the advancement of the working to the fault, the shear stress is in an increasing trend, which increases from the working surface value of $0.17 \mathrm{MPa}$ (which is $90 \mathrm{~m}$ away from the fault) to the fault value of $1.71 \mathrm{MPa}$ (which is $10 \mathrm{~m}$ away from the fault).

\subsection{FAULT ACTIVATION HAZARD ANALYSIS DURING HANGING WALL MINING}

Figure 15 shows that the ratio of the shear stress to the normal stress of the two fault zones $\mathrm{A}^{\prime}$ and $\mathrm{B}^{\prime}$ are roughly the same. For measuring point $A^{\prime}$, when the distance between the working surface and fault is greater than $40 \mathrm{~m}$, the shear stress and the normal stress increase; hence, the ratio increases, indicating that the increase in the shear stress is greater than the increase in the normal stress. The shear stress plays a leading role in the increase in the ratio. The ratio is increased from 0.013 when $90 \mathrm{~m}$ to 0.0958 when $40 \mathrm{~m}$, and the ratio of the fault at $40 \mathrm{~m}$ is the maximum value. At this time, the fault is most likely to lose stability. As the distance between the working surface and fault continues to decrease, the stress is released; the ratio of $\mathrm{A}^{\prime}$ point shear stress to normal stress decreases, which indicates that the fault has been made to be activation and instability. For measuring point $\mathrm{B}^{\prime}$, when the distance between the working face and the fault is greater than $30 \mathrm{~m}$, with the ratio of the shear stress and normal stress increase, and the ratio of the shear stress and normal stress increases. The possibility of fault activation increases gradually; when advancing to $30 \mathrm{~m}$, the ratio reaches a maximum value of 0.0947 , the fault are most likely to be activated and lose stability. When the distance between the working face and the fault is less than $30 \mathrm{~m}$, with the working face advancing, the ratio of the shear stress to the normal stress of measuring 


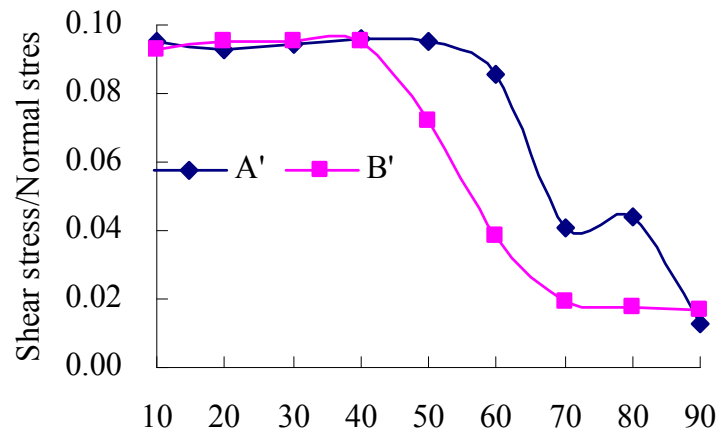

The distance from working face to fault $/ \mathrm{m}$

Fig. 15 The ratio of shear stress to normal stress mining in the hanging wall.

point $\mathrm{B}^{\prime}$ is decreasing. At this time, the fault has been activated and is unstable.

Therefore, for the hanging wall mining, highlocated strata fault zone activation precedes immediate roof. The shear stress of the fault zone is similar to that of the normal stress ratio in spatial distribution, which indicates that the variation in the shear stress plays a leading role for the stability of the fault. In the hanging wall mining, when the distance to the working face respectively from the fault are $40 \mathrm{~m}$ and $30 \mathrm{~m}$, the fault in high-located strata and immediate roof are the most likely to be activated and lose stability.

\subsection{FAULT ENERGY EVOLUTION CHARACTERISTICS DURING HANGING WALL MINING}

We can see from Figure 16, for measuring point $\mathrm{A}^{\prime}$, when the distance between the working face and the fault is greater than $40 \mathrm{~m}$, the fault does not lose stability. Along with the working face advancing, fault energy gradually increased, when the working face is $40 \mathrm{~m}$ away from fault, fault energy density reaches the maximum value of $76.89 \mathrm{~kJ} / \mathrm{m}^{3}$. When the working face is $30 \mathrm{~m}$ away from fault, the fault is activated and is unstable; the fault energy density decreases rapidly to $56.26 \mathrm{~kJ} / \mathrm{m}^{3}$, reducing by $26.8 \%$. When the distance between the working face and the fault continues to be reduced, the energy of the fault zone is relatively small. When the distance of the working face is more than $30 \mathrm{~m}$, the energy of the measuring point $\mathrm{B}^{\prime}$ fault zone increases with the advancement of the working face, and the energy density reaches a maximum value of $170 \mathrm{~kJ} / \mathrm{m}^{3}$ when the working face is $30 \mathrm{~m}$ away from the fault. When the working face is $20 \mathrm{~m}$ away from the fault, the fault shows instability and releases large amounts of energy; the energy density decreases to $46.75 \mathrm{~kJ} / \mathrm{m}^{3}$, reducing by $72.5 \%$.

When the working face advances towards the fault, the energy accumulation in the hanging wall working face is larger than the footwall working face, but after the fault activation, with the decrease amplitude of the energy, the hanging wall working

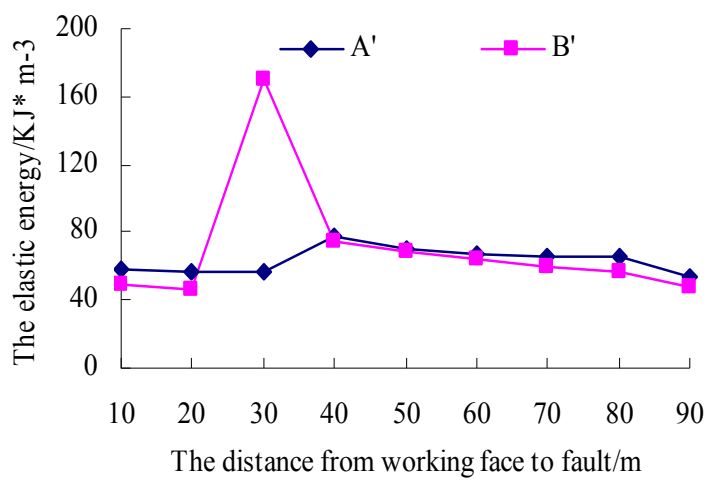

Fig. 16 Hanging wall mining fault zone energy change.

face of the fault is smaller than the footwall working face.

\section{CONCLUSIONS}

1. When the work is heading towards the fault, the barrier effect of the fault zone is evident, and the stress distribution of the overlying strata is cut off; the stress distribution on the two sides of the fault is different, and the stress concentration of the roof and floor of the fault coal pillar is relatively high. When the footwall working face is advancing to the fault, inside the fault, the overlying strata are wedge-shaped; the abutment pressure and the vertical stress of surrounding rock increases first and subsequently decrease. When the working face is $40 \mathrm{~m}$ away from the fault, in the middle of the working face, the maximum value of the support pressure is reached. Outside the fault, the vertical stress concentration of the surrounding rock is not high. The mining stress evolution law when the hanging wall advances to the fault is the same as that of the footwall. When the working face is $30 \mathrm{~m}$ away from the fault, the abutment pressure in the middle of the working face reaches the maximum value, and the abutment pressure and the vertical stress concentration is higher than that of the footwall. When the footwall or hanging wall working faces advances towards the fault, the vertical stress concentration degree of surrounding rock is high, hereby the rock burst potential increases.

2. The ratio of shear stress to normal stress of the fault zone is used as an index to estimate the stability of the fault. The shear stress plays an important role in the stability of the normal fault in the process of mining. The high-located fault activated before the immediate roof. When the lower working face respectively from the fault is $50 \mathrm{~m}$ and $30 \mathrm{~m}$, the possibility of instability of high-located fault and immediate fault is the highest. When the working face is $40 \mathrm{~m}$ and $30 \mathrm{~m}$ from the fault, the high-located fault and immediate fault are easily activated. 
3. Before the fault instability, the fault energy accumulation increases gradually, during the fault activation, large amounts of energy will be rapidly released, which can easily induce rock bursts, mine seismicity and other dynamic disasters. In addition, the fault energy can be used as an index to estimate the fault stability.

\section{ACKNOWLEDGMENTS}

This paper is financially supported by the National Natural Science Foundation of China (No. 51574155), Tai'an Science and Technology Development Plan of Shandong Province (No. 201560699) and Graduate innovation fund of Shandong University of Science and Technology (YC150307, KYKC17008).

\section{REFERENCE}

Aguado, M., Díaz, B. and González, C.: 2009, Influence of the stress state in a coal bump-prone deep coalbed: A case study. International Journal of Rock Mechanics \& Mining Sciences., 46(2), 333-345. DOI: $10.1016 /$ j.ijrmms.2008.07.005

Alber, M., Fritschen, R., Bischoff, M. and Meier, T.: 2009 , Rock mechanical investigations of seismic events in a deep longwall coal mine. International Journal of Rock Mechanics \& Mining Sciences, 46(2), 408-420. DOI:10.1016/j.ijrmms.2008.07.014

Cao, A.-Y., Dou, L.-M., Yan, R.-L., Jiang, H., Lu, C.-P., Du, T.-T. and Lu Z.-Y.: 2009, Classification of microseismic events in high stress zone. Mining Science \& Technology, 19(6), 718-723.

DOI: 10.1016/S1674-5264(09)60131-9

Cao, Y., He, D. and Glick, D.C.: 2001, Coal and gas outbursts in footwalls of reverse faults. International Journal of Coal Geology, 48(1-2) 47-63.

Chen, X.-H., Li, W. and Yan, X.: 2012, Analysis on rock burst danger when fully-mechanized caving coal face passed fault with deep mining. Safety Science, 50(4), 645-648. DOI:10.1016/j.ssci.2011.08.063

Cianciara, A. and Cianciara, B.: 2008, Method of predicting tremors on the basis of seismic emission registered in exploitation workings. Tectonophysics, 456(1), 62-66. DOI: $10.1016 / j$. tecto.2007.06.014

Gaviglio, P.: 1985, A fault and stress field analysis in a coal mine (Gardanne, Bouches Du Rhone, France). Tectonophysics., 113 (3), 349-366. DOI: $10.1016 / 0040-1951(85) 90205-7$

Hofmann, G. F. and Scheepers, L. J.: 2011, Simulating fault slip areas of mining induced seismic tremors using static boundary element numerical modelling. Mining Technology, Transactions of the Institution of Mining \& Metallurgy, Sec A, 120(1), 53-64.

DOI:10.1179/037178411X12942393517291

Islam, Md. R. and Shinjo, R..: 2009, Mining-induced fault reactivation associated with the main conveyor belt roadway and safety of the Barapukuria Coal Mine in Bangladesh: Constraints from BEM simulations. International Journal of Coal Geology, 79(4), 115130. DOI:10.1016/j.coal.2009.06.007

Jian, P., Zhao, S., Wang, S.-Q., Chang, Y. and Hui, Y.: 2016, Analysis of microseismic activity in rock mass controlled by fault in deep metal mine. International Journal of Mining Science \& Technology, 26(2), 235239. DOI: $10.1016 /$ j.ijust.2015012.008
Jiang, L., Sainoki, A., Mitri, H.S., Ma, N., Liu, H. and Hao, Z.: 2016, Influence of fracture-induced weakening on coal mine gateroad stability. International Journal of Rock Mechanics \& Mining Sciences, 88, 307-317. DOI: $10.1016 /$ j.ijrmms.2016.04.017

Jiang, Y.-D., Wang, T., Zhao, Y.-X. and Wang, C.: 2013, Numerical simulation of fault activation pattern induced by coal extraction. Journal of China University of Mining \& Technology, 42(1) 1-5.

Jiang, J.-Q., Wu, Q.-L. and Qu, H.: 2014, Evolutionary characteristics of mining stress near the hard-thick overburden normal faults. Journal of Mining \& Safety Engineering, 31(6), 881-887.

Lan, H., Chao, Qi, Q.-X., Pan, J.-F., and Peng, Y.-Y.: 2011, Analysis on features as well as prevention and control technology of mine strata pressure bumping in China. Coal Science \& Technology, 39(1), 11-15. DOI:10.13199/j.cst.2011.01.17.lanh.008

Li, Z.-L., Dou, L.-M., Cai, W., Wang, G.-F. and He, J.: 2010, Investigation and analysis of the rock burst mechanism induced within fault-pillars. Journal of Mining \& Safety Engineering, 27(4), 572-575. DOI: $10.1016 /$ j.ijrmms.2014.03.014

Li, Z.-L., Dou, L.-M., Lu, C.-P., Mu, Z.-L. and Cao, A.-Y.: 2008 , Study on fault induced rock bursts. Journal of China University of Mining \& Technology, 18(3) 321-326. DOI:10.3969/j.issn.2095-2686.2008.03.001

Liu, H.-R., Li, Z-C., Dai, J. and Tian, H.: 2014, Abutment pressure distribution and impact analysis on the plate in normal faults. Journal of Shandong University of Science and Technology (Natural Science), 23(3), 4853. DOI:10.16452/j.cnki.sdkjzk.2014.03.009

Liu, X.-S., Tan, J., Tan, Y.-L., and Hu, S.-C.: 2015, Pattern recognition of signals for the fault-slip type of rock burst in coal mines. Shock \& Vibration, 2015(6), 1-8. DOI: $10.1155 / 2015 / 806969$

Marcak, H. and Mutke, G.: 2013, Seismic activation of tectonic stresses by mining. Journal of Seismology, 17(4), 1139-1148. DOI: 10.1007/s10950-013-9382-3

Naoi, M., Nakatani, M., Otsuki, K., Yabe, Y., Kgarume, T. and Murakami, O.: 2015, Steady activity of microfractures on geological faults loaded by mining stress. Tectonophysics, 649, 110-114. DOI: $1016 /$ j.tecto.2015.02.025

Shuai, Y., Jianbiao, B., J., Wenfeng, L., Jigang, Ch. and Lei, L.: Deformation mechanism and stability control of roadway along a fault subjected to mining. International Journal of Mining Science and Technology, 22(4), 559-565. DOI: $10.1016 /$ j.ijmst.2012.01.020

Wang, Z., Yin, Z.-G., Hu, Q.-T. and Jin, H.-W.: 2010, Inducing and transforming conditions from rockburst to coal-gas outburst in a high gassy coal seam. Journal of Mining \& Safety Engineering, 27(4) 572-575.

Yu, G., Xie, H., Yu, G., Yang, L. and Zhang, Y.: 1998, Numerical simulation of fractal effect induced by activation of fault after coal extraction. Journal of China Coal Society, 23(4), 398-340.

DOI:10.13225/j.cnki.jccs.1998.04.013 